\title{
Recalibrating Asymmetric Relationships through Economic and Business Development: The Case of Lao PDR
}

\author{
*John Walsh ${ }^{1}$, Nittana Southiseng ${ }^{2}$ \\ ${ }^{1}$ Shinawatra University, Thailand \\ ${ }^{2}$ Laos-Australia Development Learning Facility, Laos \\ *jcwalsh100@hotmail.com
}

\begin{abstract}
Poor and land-locked, communist-ruled Laos began opening its economy to capitalist methods at the end of the 1980s. With a sparse population and very limited technical capacity, the country's principal economic activities involve foreign investors building dams for hydroelectricity or mining for minerals that are destined for export. The local economy is dominated by small and uncoordinated enterprises operating in mostly undeveloped and unsophisticated markets. Laos is in the process of becoming more integrated into the Mekong Region by virtue of the building of parts of the Asian Highway Network across its territory and some opportunities arising from the planned single market of the ASEAN Economic Community which reaches a new phase in 2015. The vision is for Laos to become a bridge for economic development. However, it is not clear that the mere presence of infrastructure will be sufficient for Laotian companies and institutions to receive benefits on a substantial and sustainable basis. Principal difficulties are (i) underdeveloped public human resource capacities and institutional support systems, (ii) lack of industry clusters and facilities that can provide SMEs access to regional and global value chains and (iii) limited endowment of resources, logistics, finance and limited capabilities to meet market demand. This paper examines the conjunction between ability of Lao actors to participate in emergent economic activities and the country's ability at government level to articulate its own developmental priorities and attempt to achieve these through negotiation with other states. This requires seeking to recalibrate hugely asymmetric relationships with China, Japan and Thailand, among others.
\end{abstract}

Keywords: Recalibrating, Asymmetric Information, Economic Development

\section{Introduction}

This paper examines the situation of Laos as a small, landlocked state sandwiched between neighbors which have over the years been able to enforce a variety of hegemonic powers over it. Vietnam has enforced ideological hegemony, Thailand a market hegemony and, now, China, through its large-scale provision of capital, has been able to enforce hegemony of development trajectory. These events indicate the smallness and weakness of Laos as a state in the system (i.e. the Mekong Subregion) that it inhabits. However, other countries in that Subregion have been small and weak in their time and yet have progressed to be able to exert hegemonic forces of their own. What, if anything, then, is different about Laos and how can the changes that have been observed and are now emergent be best understood? These are the central questions that are under consideration in this paper. To attempt to understand the changes and the reasons for them, a neo-Gramscian approach is adopted since it is receptive to analysis of dynamic circumstances and sensitive to determining the connections at sub-state level operation on a cross-border basis. For historical and conceptual reasons, it is these cross-border connections that, it will be argued, are vital to understanding Laos as a small state. This form of approach contributes to understanding not just of Laos and its development trajectory but also of other comparatively small states which are faced by hegemonic neighbors. The paper continues with a discussion of the neoGramscian framework of analysis employed to evaluate the situation, followed by a consideration of the modern history of Laos as a small state and, then, analytical sections considering Laos and its progress in neo-Gramscian perspective and sections concerning asymmetric relationships and the role of infrastructure in determining development trajectory. A conclusion ends the paper.

A Neo-Gramscian Framework of Analysis: In analyzing the relations between Laos and external powers, a neo-Gramscian framework is employed, as elucidated by Cox $(1981,1983)$.This framework rests on three sets of factors: the social relations of production; the forms of state and world orders. These factors are dynamic rather than static in nature and, therefore, are able to help explain the different forms of hegemony under which Laos has labored throughout modern history. This approach also sheds 
light on the changes that are currently occurring and are likely to occur in the foreseeable future. The dynamic nature of the approach has the additional benefit of avoiding the problems resulting from treating discrete variables as continuous variables in analysis (King, 1989); it focuses, that is, directly on processes rather than events. It also has the benefit that is does not presuppose that the interests of the state are directly and invariably enacted by the government and its agencies and, also, that an intermediate level between the macro or national and micro levels is suitable for analysis (Gale, 1998).It is, after all, the relationship between state-level interests and international corporations that can be of critical importance to an emerging or developing state such as Laos (Strange, 1996:9).

The social relations of production are composed of all the tangible and intangible factors that are involved with the production process and cause or influence it to change. In this paper, particular attention is placed on the role of infrastructure in affecting the social relations of production. Forms of state relates to the changing configuration of social classes and alliances that provide a means of control of the levers of government. Currently, the issues within forms of state in Laos relate to the declining importance of political legitimacy compared to economic legitimacy and the increasing role of Chinese capital and organizations. Finally, world orders relate to the overarching configuration of hegemonic states and powers occurring at a particular moment of time, again in the context of continued change. There are several important changes taking place within the Mekong Subregion within which Laos is located and linking that region to other blocs within Southeast and East Asia and beyond. The linking of Laos via the Mekong Subregion to distant international markets by the means of the Asian Development Bank's (ADB) Asian Highway Network (AHN), thereby hoping to create a new regional economic power, is one example of change in world order in action at the present.

A final force to be considered in this framework is the concept of new constitutionalism disciplinary neoliberalism (Gill, 1992).This is the force that aims to restrict the ability of individuals and organizations within the civil or public sector from criticizing or questioning the role and primacy of economic power. Laos, in common with the rest of the Mekong Subregion, has a number of factors that act to restrict public discourse through restrictions on freedom of speech and of association. Historically, these forces have acted to protect political and establishment elites and the change now is to add economic elites to that category rather than to change the underlying system. The means by which this is happening is primarily through accumulation by dispossession (Harvey, 2006:41-50).That is, forces are being mobilized to convert commons into private property commodities which are then extracted from their previous owners and made available, if at all, via market mechanisms.

It is acknowledged that the use of a Neo-Gramscian framework is not considered unproblematic. The concepts employed have been brought into question and the need for appropriately thorough historicisation of the context examined stressed (Germain \& Kenny, 1998).However, the approach benefits not just from the flexibility provided by explicit recognition of the dynamic nature of change between and among the factors considered, which separates it from the World Systems approach but, also, in its recognition that international relations does not just depend on state-level actors but also on transnational forces. In this, it has something in common with the social constructivist approach (Keck \& Sikkink, 1999).In the case of Laos, the extension of advanced capitalism into the country has led to the increasing connection at horizontal levels between different fractions of classes within states and across borders (Poulantzas, 1975:73-6).This reconfiguration of relationships and alliances complements the use of state power in the imposition of hegemonic norms and ideals upon a people. Hegemony is a critical function of the state, along with dictatorship (Gramsci, 1979:239).Even this, which is widely considered to be Gramsci's principal contribution in this area, has been challenged: as a sometime follower of Machiavelli, his description of the 'transformative realism' has, it has been argued, more properly located him and his approach somewhat closer to the realist school than is widely believed and, indeed, this has been the approach taken in this paper (Femia, 2005). There are, in any case, various ways of reading Gramsci and re-presenting his work (Satgar, 2013).

\section{Laos as a Small State}

While noting the difficulties in providing a suitable definition that covers every state within the category, Hey (2003) considers smallness as a state to be a term that refers to weakness both in terms of size and of wealth. The smallness contributes to a lack of ability to influence other states and to take actions to improve their own positions. It is possible for small or micro-states to wield significant levels of influence in international relations (e.g. Peterson, 2006)if they, for example, possess valuable resources, such as oil, 
or a unique cultural-historical position, for example the Vatican, that may be used to wield power unrelated to purely physical capacity. There is little doubt that the People's Democratic Republic of Laos ('Lao PDR') conforms to the characterization of a small state. Its physical size is not that small, since it occupies more than 236,000 square kilometers of land. However, away from the valley of the River Mekong which forms much of the lengthy western border, a large proportion of Lao PDR is mountainous, thickly forested and mostly unsuitable for dense population settlements. Indeed, the total population of the country is a little over 6.5 million and the only large urban areas are the capital Vientiane, the historical capital LuangPrabang and provincial market towns such as Savannakhet. Low levels of income per head, high levels of infant mortality and the outward migration of so many young adults helps paint the picture of a country which is surrounded by richer neighbors with more attractive standards of living. Lao PDR has borders with China to the north, Vietnam to the east, Cambodia to the south, Thailand to the west and Myanmar [Burma] to the northwest. Geographical, historical and cultural factors make the relationships with Vietnam and Thailand generally more important than the others. The country is also land-locked and, as a result, suffers a significant loss of income. Coastal access is important for both the import and export of goods and countries which do not have it must rent it from neighbors. A land-locked country is, therefore, dependent for its ability to develop economically on the political and diplomatic conditions of others (Feye et al., 2004).

The majority of the population of Lao PDR is part of the Tai diaspora that has spread over the past millennium from its origin somewhere in Northwest Vietnam or Southeast China as far as Assam in the west to Guangxi and Hainan to the east and as far south as the Malaysian border of Thailand. Most ethnic Lao people live on the western bank of the River Mekong, in the northeastern Thai region known as Isaan. In the Lao imagination, the Mekong runs along the middle of the Lao nation: in political reality, it divides the people into two unequal portions (Walsh \& Southiseng, 2009).This division of the nation is indicative of the history of the Lao people. For some centuries, the Lao people organized successful, independent city-states (muangs) based on LuangPrabang in the north, Vientiane in the central region and Savannakhet in the south. These muangs were resilient in the face of endemic warfare in the region featuring adventuresome Siamese (i.e. Thai) and Vietnamese princes and generals. Warfare was based on control of people in a region that was historically lacking in population. As a result, campaigns were aimed at the capture and relocation of populations, particularly the skilled workers of urban populations, rather than territorial control. The system of Mekong relations changed decisively with the arrival of British colonial interests in Burma (now Myanmar) and Malaya (now Malaysia and the French interests in Indochina (Vietnam, Cambodia and Laos). Military technology and infrastructure deepened and Lao communities were relocated en masse to Isaan settlements on the Korat Plateau and the northern city of Chiang Mai as part of what has been described as a war of attempted genocide. The 1827 campaign was decisively lost (Ngaosyvathn \& Ngaosyvathn, 1998).The victory by the Siamese made that country sufficiently strong and self-confident to stand as an independent state in the colonial age and to become a buffer between the British to the west and the French to the east, who annexed Laos alongside Vietnam and Cambodia in a state to become known as Indochina. Milton Osborne (1997:32), one of the principal historians of the period, has described the French entry into Cambodia as an 'afterthought. 'The entry into Laos was anterior even to that.

Vientiane had already been abandoned by that point and its buildings fallen into desuetude. By the time the French took formal control of Laos as a byproduct of the Franco-Siamese Treaty of 1893, Vientiane had been sacked by the Ho ('Chinese' bandits) searching for gold and treasure in the few remaining wats (temples) still standing. The French authorities recognized that the location of the city would be an appropriate place to construct a provincial administration centre in a place where the "... pre-colonial morphology had ... largely vanished between the forest and undergrowth (Kogan, 2007)."Laos produced few usable resources and its administration was regarded as a suitable posting for junior or problematic colonial officials. The 'civilizing mission' that characterized French colonialism was concentrated primarily in Vietnam, where large urban centers provided targets for the religiously-motivated, while the installation of rubber plantations in Cambodia attracted the commercially-minded. The sparse Lao population, in its farming villages and communities, continued much as before. Largely bereft of any class of intelligentsia, few if any Laotians contributed to the formation of the Indochinese Communist Party (ICP) or any other political-intellectual approach to nationalism or independence. Some at least of the efforts that were aimed at independence were millenarial in nature and reliant upon the charisma of supposedly spiritually-advanced individuals (Gay, 2002).The ICP fell primarily under Vietnamese sway and the relationship with Lao nationalists became characterized as one of big brother to little brother, which is the relationship that many argue has persisted to the current day. The First and Second 
Indochinese Wars which ultimately brought freedom from colonization in the region were primarily fought in Vietnam, while fighting in Laos took the form either of Special Forces activities or of aerial bombardment of suspected insurgents and their sympathizers. The Lao people have the dubious distinction of being, per person, the most heavily bombed in the world. Unexploded ordnance remains a significant threat to the Lao people, particularly in rural areas (Khamvongsa \& Russell, 2009).

The 1975 revolutionary victory of the Pathet Lao Party introduced the rule of a faction ideologically in thrall to its eastern counterpart and also reliant upon external forces, notably the Soviet Union. Between 1975-9, the newly Communist Lao state enjoyed a degree of independence in its foreign policy but the special relationship with Vietnam meant this ended in 1979, after the Vietnamese invasion of Cambodia brought an end to the Khmer Rouge regime (Stuart-Fox, 1996:201-11).Open membership of Laos in Vietnam's political bloc was decisive when it came to the relationship with China, which became evident during the Sino-Vietnamese War (1979). Deng Xiaoping was already involved with making the Open Door Policy a reality and opening relationships of new friendship with various states. The inability of the Soviet Union to provide assistance following the break-up of the system meant that one of Laos' (and indeed Vietnam's) principal sponsors had withdrawn without much notice and this threatened bankruptcy to them. China was unwilling to help, for not only had the Vietnamese connection proved problematic but skirmishes along the lengthy but undemarcated Laos-China border also led to tension (Storey, 2011:16575).However, the Lao government's proclamation of the New Economic Mechanism, following in the wake of Vietnam's DoiMoi policy and with similar apparent aims, found the Chinese willing to build bridges with potential partners to the south and, to cement the relationship, financial support was received following the 1997 Asian Economic Crisis. The accession of Laos to the Association of Southeast Asian Nations (ASEAN) coincided with China's embrace of the organization and intention to bring a large integrated southern market into its orbit as a source of additional resources.

The twenty first century has seen Laos progressively opening itself to the outside world and accepting international, regional and global influences. Somewhat paradoxically, the single principal cultural influence is from the ethnic Lao subjects of the Kingdom of Thailand on the other side of the River Mekong, whose familiar dialogue both fuels the potential (in some minds) of an independent or at least autonomous Isaan and also an awareness of the complexity of multiple and sometimes divided identities (Hesse-swain, 2006).Once again, then, Lao state and people have become aware of the presence of more powerful neighbors outside their borders and the possible threat they might cause. As a means of cooperation and co-existence, not to mention profit-making, the resources of the country have been made available to international investors and the proceeds divided according to more or less equitable criteria.

\section{Infrastructure Development in the Age of the New Economic Mechanism}

Infrastructure in this paper refers primarily to the transportation infrastructure of roads and bridges and the attendant utility and power lines that generally follow along their length. There will also be some brief reference to aerial transportation infrastructure but, since Laos has neither coastline nor any working railroad, boats and trains will be largely omitted, apart from those stretches of the Mekong along which riverine trade is beginning to flourish. Owing to limited resources available to many Asian governments, the ADB has been active in planning and conducting the construction of infrastructure networks. The capital involved is largely Japanese in origin and the motivations for employing it for this purpose complex and multivalent. The economic argument for the ADB's network of highways was set out in a recent working paper:

"Connecting countries through roads is a pivotal element of regional integration. Such connectivity across borders brings many benefits, including improved competitiveness of production networks, better trade flows, and reductions in development gaps between rich and poor countries (Madhur, Wignaraja \& Darjes, 2009)."

In the case of Lao PDR, the landlocked nature of the country is to be turned into a bridge or an integral part of a network. Its improved connectivity will, it is envisaged, enable domestic and international investors to make the most of emergent opportunities. Research at a smaller scale has suggested that bridge construction unleashes creative destruction in local commercial systems which enables non-local actors to leverage their additional resources to replace local arbitrage opportunities and the people who have been benefiting from them (Gomez et al., 2011).There is also considerable evidence that, partly because of collusion with government agencies, incoming investors have been able to annex, on a semiformal basis, parcels of land which are then ruled by a parallel or shadow form of authority, if they are 
placed under the control of an international government agency or, else, are turned over to a form of cowboy capitalism. The Chinese government, for example, uses its large corporations to help in completing its overseas development and foreign policy goals and these include the construction of largescale infrastructure projects which, in part, are designed to help in the transfer of resources to its own territory. The areas surrounding these projects are in effect turned over to Chinese control; when territory is taken over by non-governmental activities on the other hand, the emergent casino-karaoke economy is dominated by cowboy capitalist leadership. An example of this is the Boten Golden City, in which only Chinese is spoken and only Chinese currency is accepted. Public order is maintained to help encourage gamblers to feel secure but there are few rights or protections for the workers (Swe \& Chambers, 2011:86-8).These non-state areas have become available to investors because of their connection with the transportation infrastructure, which has made their exploitation potentially profitable. Although some individuals with government connections may have benefited from these activities, it is difficult to see how the country as a whole is benefiting from the changes that have occurred. Resources are extracted, often on an unsustainable basis, and the proceeds transferred elsewhere. The ADB itself has struggled to provide credible estimates of the rate of return of transportation infrastructure as a whole, let alone their division according to geographical territories. What its construction does seem to have led to is the increased commodification of Laotian space and its assignment to the capitalist mode of production.

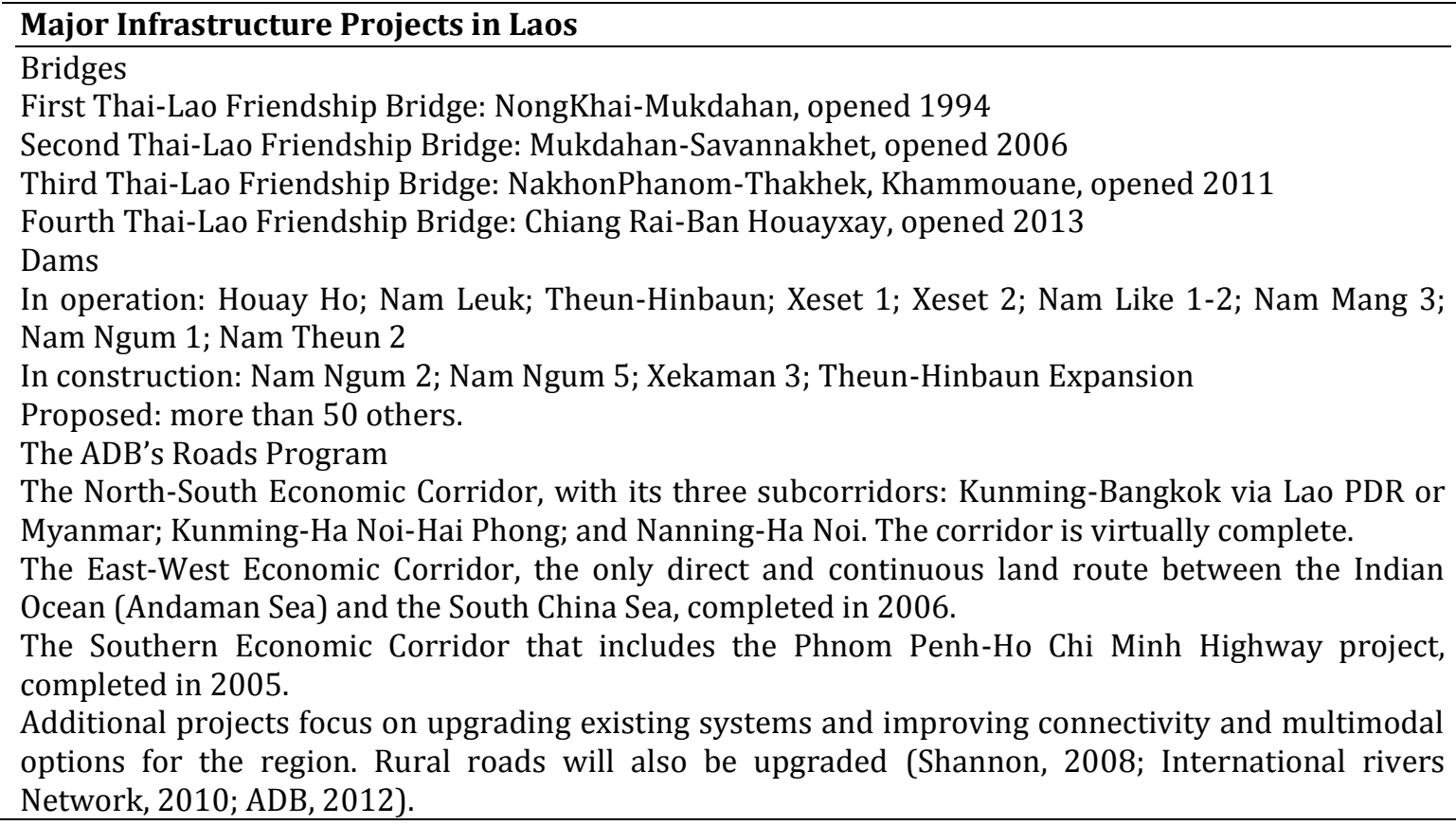

Major infrastructure projects, as outlined above, exist to link major (or potentially major) production and consumption centers across borders or else to generate resources for extraction to those production and consumption centers, again across borders. Lao PDR exists as host to places where income can be generated, therefore, without being a place where the resources produced can be marketed because of the very limited size and spending power of people in the local markets. It is also notable that roads have to date been privileged above rail and air transportation - although there of course ambitious plans for railroads linking the region with Chinese cities, perhaps even with high-speed links using Chinese money. Roads provide the most convenient means for capitalist accumulation in the Mekong Region.

Laotian History in Neo-Gramscian Perspective: As observed previously, the Neo-Gramscian approach employed in this paper rests upon the analysis of three principal areas: social relations of production; state forms and modes of world order. This section of the paper analyses Laotian history with respect to these three factors.

Social Relations of Production: Prior to colonization, Laos was dominated by subsistence agriculture in a variety of formats, from wet-rice paddy farming to high mountain slope swiddening ('slash and burn 'agriculture) and many more in-between. Each of these forms of agriculture may be considered a primitive form of accumulation. Temporal rulers exacted corvée labor and taxes from those villagers who 
were not able to escape into the forest in time, while the monks who represented the spiritual world were supported at the village or community level through voluntary donations in kind or labor. A labor force per se did not exist at this time in the sense that people's efforts were not yet commodified and placed for sale in any market place. The governance changed as a result of colonization, with a small number of French individuals introduced as provincial administrators, supported by mostly Vietnamese officials at junior levels (Stuart-Fox, 1997:32).The French regularized pre-existing conditions with respect to the imposition of corvée labor and taxation. These were initially set at the same levels imposed by the nowsupplanted Siamese overlords but the rents extracted by the subordinate Lao nobility who actually collected the head taxes were redirected as far as possible to French coffers. Attempts were also made to suppress the extensive slave trade and the prevalent practice of debt slavery. However, the difficulty in making the colony at least pay for its own administration became evident almost at once and this persisted until the end of the French presence. This period may be characterized, therefore, as one of typical imperial extraction of resources, mitigated only by the fact that the imperialists found comparatively few resources to extract.

The period between the Second World War and the 1975 revolution may be characterized as one in which petty capitalism began to spread, at least to a limited geographic extent, across the Laotian economy. Vientiane and some of the border crossing areas adapted some characteristics of production and consumption centers, albeit that consumption outweighed production and a great deal of foreign aid from the USA was involved. A significant amount of production took place in the service sector connected to the presence of overseas officials and was later condemned as being decadent and its practitioners obliged to join re-education camps. At this point, very little of the productive economy had moved beyond the primitive accumulation stage and it was the Pathet Lao that sought to integrate more of the economy into a modernizing state, primarily through the imposition of collectivization. For geographic and climatic reasons, this approach failed and was withdrawn, along with a number of other policies which were resisted for cultural and historical reasons. The state expanded its size and scope and more people were drawn into its employ. Foreign experts, including those from the Soviet Union and Vietnam, helped transfer some knowledge from outside the Laos into the local economy. Capacity increased, albeit of course from a low base. As more people were drawn into the waged sector, more opportunities for entrepreneurial and commercial activities emerged, particularly in urban areas and this increased the tendency for migration from countryside to city to take place. Nevertheless, very few large scale industrial activities took place in this period.

Since the announcement of the naesetthakitmae (New Economic Mechanism - NEM) policy in 1986, the country has become much more open to inward foreign direct investment and this has signaled its entry into the factory age. To date, most inward investment has focused on the resource extraction industries, since various valuable minerals have been located and are being removed by transnational mining firms. A second area of activity has focused on the construction of dams to generate hydroelectric power, mostly for export to Thailand, owing to limited domestic demand. Generally, this change has transferred power over production processes to international investors. When Lao people have been involved with working on such projects it has been at a comparatively low level; entrepreneurs have been active in supplying products and services to large operations and there has been some limited support from the government, mostly via international non-governmental organizations (INGOs).

\section{Forms of State}

Lao PDR has passed through several distinctive changes in state formation in the period under consideration. Initially, it was an absolute monarchy which used a combination of religious indoctrination, decentralized power to junior members of the nobility and the threat of violence to demonstrate legitimacy and maintain order. Under the colonial state, Laos was governed by a coalition of French officials and Vietnamese assistants for the benefits of the colons who were intended to make this province of Indochina yield a profit. The French state was superseded by a short-lived nationalist government that featured an alliance between elements of the monarchy network, international aid providers and early capitalists. The mass of the people remained in disempowered dispersal across the countryside. The Pathet Lao, taking power in 1975, broadened the ruling class within the Lao people by incorporating Party members to replace the aid donors and dynastic relics who were all banished. Party members acted in solidarity with Communist Party members from the Soviet Union and Vietnam. To a certain extent, the Pathet Lao leadership was able to incorporate new members of the population who were able to access education scholarships or technical training from international allies, although 
sometimes in unexpected ways (Evans, 1999).Nevertheless, the proportion of the population that was included in the ruling classes remained comparatively small. The ability of the Pathet Lao to act independently was also greatly constrained by the influence that international allies wielded, especially with respect to relationships with China, Japan and Thailand. The situation has changed with the implementation of the NEM as international investors have joined the ruling alliance, as too have those members of the pre-existing alliance who have been able to redefine themselves as legitimate leaders on an economic rather than a political basis. Members of INGOs have also reestablished themselves as important elements within the ruling coalition by means of the resources they are able to deploy. In the case of both Japan and China, the apparently disparate categories of INGOs and commercial operations are in fact united as a means of pursuing the national interest.

World Orders: Hegemonic power has switched from European imperialists to the matched opposition of the Cold War, through the unipolar world of American domination and into the period of the rise of Chinese influence. The nature of that hegemony has also varied in nature, if not perhaps in intent. Colonial power relied to some extent on the willingness of Laotian nobility to continue with their intermediary roles in ensuring that revenue collection and public order can take place. Ideology was important in persuading people to embrace deference and a fatalistic approach to life that, generally, precludes rebellion. Subsequent means of control was obtained through military power and a universal application of ideology on a compulsory basis. Where contradictions between different ideologies became apparent, attempts were made either to eradicate the earlier and now discredited belief or else to persuade individuals to change their understanding. The nature of ideology has changed since the promulgation of the NEM in that it has been based on the free spread of capitalism and the government's willingness to embrace the market-friendly policy stance of the Washington Consensus. Military power has also diminished in importance as more attention is given to the ability of an actor to provide opportunities for income generation and for personal enrichment. The rise in influence wielded by Chinese interests does not involve any attempt to promote Maoist conformity within Vientiane's seats of power and everything to the ability of Chinese organizations to provide the opportunities for people to become rich and to delegate such opportunities to others. This Neo-Gramscian analytical approach helps in understanding of how changes have manifested themselves within the modern Lao state. It is next necessary to relate this framework to the role Laos has a small state in asymmetric relationships with external powers.

Relationships between the Analytical Framework and the Small State Aspect: The historical analysis presented above highlight the ways in which hegemonic control of Laos has varied as the nature of control over the means of production has also varied. That is, a combination of ideology and compulsion has been used in various configurations to ensure a stable social and political hierarchy. This has resulted generally from leadership from the outside: colonial power, ideological leadership, capital provision. To some extent, according to the neo-Gramscian approach, it does not matter so much from an aggregate development perspective which leader is active if the leadership results in an overall increase in the number of resources available through the action of a positive sum game (Arrighi, 2007:150).However, it has historically been the case that the intervention of external powers in Laotian territory has represented a zero sum game. This was true of Siamese depredation through to the actions of the Cold War. The spread of advanced capitalism represents a positive sum game, albeit one in which the gains are distributed unequally. For example, per capital Gross National Income has risen from US\$620 in 2007 to US $\$ 1040$ in 2010 (Atlas method), although 33.9\% of the population are living on less than US\$1.25 per day and 27.6\% are living at below the nationally defined poverty level (ADB \& Lao PDR, 2012).In other words, benefits are being captured by some sections of the population and not equally. As and when Lao PDR follows the same route to rapid modernization previously adopted by Thailand, Vietnam and China, which centers on the factory world, then relatively large numbers of rural workers will be drawn to special economic zones and subjected to the alienation of scientific management. That process will lead to remittance of some salaries and the long and difficult movement towards regional development. However, this has not yet begun because of the low level of population in the country, which has made market-seeking activities undesirable and the low level of infrastructure and, therefore, high transaction costs have made resources (low labor-cost) seeking activities unprofitable. The neo-Gramscian approach explains these changes better than a variant of the realist approach would do in that the cross-border connections and their dynamic nature are more evident. This is particularly relevant to a small state such as Laos because it helps explain why, lacking resources and capacity, a process of change can nevertheless be set in train. 
Asymmetric Relationships: One of the principal means by which small state status is expressed in the case of Laos is through the creation and maintenance of asymmetric relationships. These relationships, which would once have been forged by military or hard power, are now the result primarily of economic power, although there is some limited use of cultural forms of hegemony. Since economic power results from the imposition of capitalism on systems that were previously pre-capitalist in nature, a dialectical process may be observed in that the creative destruction brought about by this changes the nature of the place in which investment takes place as well as the investor. For example, investment by Chinese organizations provides some revenue for the Lao PDR government which gave it the confidence to resist further expansion deemed unacceptable by local people. This occurred with respect to the so-called Chinatown that had been scheduled to be built in the vicinity of Vientiane and peopled with, so it has been reported, hundreds of thousands of inwardly migrating Chinese (McCartan, 2008).This project has been postponed. However, there has been less success with the issue of land grabbing or the awarding of land concessions for commercial exploitation, depending on perspective. As in neighboring Cambodia and Myanmar, investors have organized alliances with local officials to obtain access to land for various forms of agricultural production. This provokes resentment among local people who find themselves expropriated and the land they had once known has been converted into a commodity. The disruption that people may suffer from ancestral homelands may be considerable and, in the case of Laos, exacerbated by the presence of wartime memories at various scales which are not easily mapped or understood by outsiders (Baird \& Le Billon, 2012).However, resistance at lower spatial levels seems not to be matched very often at the state level.

The Lao PDR government has agreed to participate in Mekong Subregion-wide development projects and, indeed, has had little choice but to do so - which integrate the country into larger economic areas. This will provide further market opportunities for Lao farmers to service Thai markets and in return purchase Thai and now Chinese manufactured items. Since there are few established Lao brands or commercial enterprises with the managerial knowhow to compete in the consumer goods marketplace and most Laotian consumers are relatively unsophisticated in consumer behavior and make decisions almost entirely on the basis of price and availability, then Lao producers continue to rely on basic, primary products (e.g. agricultural or aqua cultural items) and in providing utility by splitting packets for sale into smaller units (Walsh \&Southiseng, 2011).It is possible for local businesses to compete with international rivals but the practice to date has been for international investors to dominate the principal areas of any potentially profitable economic sector and for Lao-managed alternatives to act as low cost alternatives or in support services for international firms (e.g. Southiseng\& Walsh, 2011).To date, efforts to promote micro- and small and medium-sized enterprises and their entrepreneurs in the country have been limited, subject to resource constraints and inappropriate allocation, as well as the difficulties inherent in persuading finance institutions to lend to such entrepreneurs. Until these issues are addressed appropriately, asymmetric relationships in the commercial sphere will remain problematic. Asymmetric relationships exist, to an extent symbolically, with Thailand as the source of markets and production centers, with China as the extractor of resources and producer of new forms of capital formation and with Japan in connection with the nexus of activities that surround overseas development assistance and the activities of the ADB. The development of local capacity in the form of business and commercial infrastructure would offer means of countering the hegemonic influences of these asymmetric relationships while converting them to new configurations of resources and power able to move on to the next territories.

\section{Conclusion}

Sectors or classes within an economy or state change and develop at different rates as a result of processes of globalization. Those which tend to develop fastest are those which can create cross-border alliances of mutual interest with partners following the same trajectory but having moved further forward already. However, globalization in current conditions also forces open economies so that those same international interests can establish themselves in a small state, supplanting local would-be competitors and establishing relationships with important institutions as a means of suppressing that local competition. This is the difference between large and small states. As a small state, Laos faces the threat of having its means of development taken over by cross-border concerns which can be assumed to be following their own interests and not those of any state in whose territory they might be operating. The history of rapid development in East Asia has commonly been driven by state governments being able to find ways to coerce their business organizations into meeting state-level developmental goals, in part through interaction with non-state actors or meso-level state actors arising from other countries. A 
small state may not be able to follow the same route and enter instead a state of permanent underdevelopment: East Asian neighbors have achieved success by having national commercial enterprises available for direction towards state-level developmental goals, at least for a period of time until those enterprises have been able to create the conditions for their own independence. Laos does not have these enterprises.

This paper has sought to make a contribution to understanding the development trajectory of Lao PDR through using a neo-Gramscian analytical framework that has successfully provided a structure for the arguments provided. It has been stressed that Lao PDR is a small state surrounded by more powerful neighbors that have been able to enforce hegemonic control over the country by means of different dimensions of power. Given the lattice of power relations increasingly enfolding the country, it is difficult to imagine how it could break free of them and forge a route of self-determination.

\section{References}

Arrighi, G. (2007). Adam Smith in Beijing: Lineages of the Twenty-First Century, London and New York: Verso.

Asian Development Bank (ADB) and Lao People's Democratic Republic. (2012). Fact Sheet (April), available at: http://www.adb.org/sites/default/files/pub/2012/LAO.pdf.

Asian Development Bank (ADB). (2012). Overview: Greater Mekong Subregion Economic Cooperation Program, Manila: ADB, available at: http://www.adb.org/sites/default/files/gms-overview.pdf.

Baird, I. G. \& Le Billon, P. (2012). Landscapes of Political Memories: War Legacies and Land Negotiations in Laos. Political Geography, 31(5), 255-334.

Cox, R. W. (1981). Social Forces, States and World Orders: Beyond International Relations Theory, Millennium. Journal of International Studies, 10(2), 126-55.

Cox, R. W. (1983). Gramsci, Hegemony and International Relations: An Essay in Method, Millennium. Journal of International Studies, 12(2), 162-75.

Evans, G. (1999). Apprentice Ethnographers: Vietnam and the Study of Minorities in Laos, in Grant Evans, ed., Laos: Culture and Society, Chiang Mai: Silkworm Books, 161-90.

Faye, M. L., McArthur, J. W., Sachs, J. D. \& Snow, T. (2004). The Challenges Facing Landlocked Developing Countries. Journal of Human Development, 5(1), 31-68.

Femia, J. (2005). Gramsci, Machiavelli and International Relations. The Political Quarterly, 76(3), 341-9.

Gale, F. (1998). Cave 'Cave! Hic Dragones': a Neo-Gramscian Deconstruction and Reconstruction of International Regime Theory. Review of International Political Economy, 5(2), 252-83.

Gay, B. (2002), Millenarian Movements in Laos, 1895-1936: Depictions by Modern Lao Historians, in MayouryNgaosrivathana and Kenneth Breazale, eds., Breaking New Ground in Lao History: Essays on the Seventh to Twentieth Centuries, Chiang Mai: Silkworm Books, 281-96.

Germain, R. D. \& Kenny, M. (1998), Engaging Gramsci: International Relations Theory and the New Gramscians. Review of International Studies, 24(1), 3-21.

Gill, S. (1992). The Emerging World Order and European Change: The Political Economy of European Union, in Ralph Miliband and Leo Panitch, eds., The Socialist Register: New World Order? London: Merlin Press.

Gomez, J. E. Jr., Southiseng, N., Walsh, J. \& Sapuay, S. (2011). Reaching across the Mekong: Socioeconomic and Gender Effects of Lao-Thai Crossborder Linkages. Journal of Current Southeast Asian Affairs, 30(3), 1-23, available at: http://hup.sub.uni-hamburg.de/giga/jsaa/article/view/473/471.

Gramsci, A. (1971). Selections from the Prison Notebooks of Antonio Gramsci, New York: International Publishers, 1971, translated with an introduction by Quintin Hoare and Geoffrey Nowell Smith.

Harvey, D. (2006). Spaces of Global Capitalism: Towards a Theory of Uneven Geographical Development, London and New York: Verso.

Hesse-Swain, C. (2006). Programming Beauty and the Absence of Na Lao: Popular Thai TV and Identity Formation among Youth in Northeast Thailand. Geo Journal, 66(3), 257-72.

Hey, J. A. K. (2003). Introducing Small State Foreign Policy, in Jeanne A.K. Hey, ed., Small States in World Politics: Explaining Foreign Policy Behavior, Boulder, CO: Lynne Rienner Publications Inc., 1-12.

International Rivers Network. (2010). Existing and Planned Hydropower Projects (September, 2010), available at: http://www.internationalrivers.org/files/attachedfiles/laohydro2010_sept_final.pdf.

Keck, M. E. \& Sikkink, K. (1999). Transnational Advocacy Networks in International and Regional Politics. International Social Science Journal, 51(159), 89-101. 
Khamvongsa, C. \& Russell, E. (2009). Legacies of War: Cluster Bombs in Laos. Critical Asian Studies, 41(2), 281-306.

King, G. (1989). Event Count Models for International Relations: Generalizations and Applications. International Studies Quarterly, 33, 123-47.

Lawrence, S. (2008), Power Surge: The Impacts of Rapid Dam Development in Laos, Berkeley, CA: International Rivers Network, available at: http://www.internationalrivers.org/files/attachedfiles/intl_rivers_power_surge.pdf.

Logan, W. (2007), Land of the Lotus-Eaters: Vientiane under the French, in Marc Askew, William S. Logan and Colin Long, eds., Vientiane: Transformation of a Lao Landscape, London and New York: Routledge, 73-110.

Madhur, S., Wignaraja, G. \& Darjes, P. (2009), Roads for Asian Integration: Measuring ADB's Contributions to the Asian Highway Network, ADB Working Paper Series on Regional Economic Integration, 37 (November), available

at: http://aric.adb.org/pdf/workingpaper/WP37_Roads_for_Asian_Integration,pdf.

McCartan, B. (2008). New-Age Chinatown Has Laotians on Edge, Asia Times Online (July $26^{\text {th }}$ ), available at: http://www.atimes.com/atimes/Southeast_Asia/JG26Ae02.html.

Ngaosyvathn, M. \& Ngaosyvathn, P. (1998). Paths to Conflagration: Fifty Years of Diplomacy and Warfare in Laos, Thailand, and Vietnam: 1778-1828, Ithaca, NY: Cornell University Press.

Osborne, M. E. (1997). The French Presence in Cochinchina and Cambodia: Rule and Response (18591905), Bangkok: White Lotus, 1997 [first published 1969].

Peterson, J. E. (2006). Qatar and the World: Branding for a Micro-State. Middle East Journal, 60(4), 732-48.

Poulantzas, N. (1975). Classes in Contemporary Capitalism, London: New Left Books, translated by David Fernbach.

Satgar, V. (2013), Transnationalising Gramscian Marxism, in Michelle Williams and VishwasSatgar, eds., Marxisms in the $21^{\text {st }}$ Century, Johannesburg: Wits University Press, 53-81.

Southiseng, N. \& Walsh, J. (2011). Study of Tourism and Labour in LuangPrabang Province. Journal of Lao Studies, 2(1), 45-65, available at: http://laojournal.org/index.php/promote/article/view/16/16.

Storey, I. (2011). Southeast Asia and the Rise of China, Abingdon and New York: Routledge.

Strange, S. (1996). The Retreat of the State: The Diffusion of Power in the World Economy, Cambridge: Cambridge University Press.

Stuart-Fox, M. (1997). A History of Laos, Cambridge: Cambridge University Press.

Stuart-Fox, M. (1996). Buddhist Kingdom Marxist State: The Making of Modern Laos, Bangkok: White Lotus.

Swe, T. \& Chambers, P. (2011). Cashing in across the Golden Triangle: Thailand's Northern Border Trade with China, Laos, and Myanmar, Chiang Mai: Mekong Press.

Walsh, J. \& Southiseng, N. (2011). Understanding and Strengthening the Health of Family Businesses in Laos. Information Management and Business Review, 2(1), 12-18, available at: http://www.ifrnd.org/IMBR/2(1)\%20Jan\%202011/Understanding\%20and\%20strengthening_h ealth\%20of\%20family\%20businesses.pdf.

Walsh, J. \& Southiseng, N. (2009). Vientiane: A Failure to Exert Power? City: Analysis of Urban Trends. Culture, Theory, Policy, Action, 13(1), special issue, 95-102. 